\section{EREM 72/4}

Journal of Environmental Research, Engineering and Management Vol. 72 / No. 4 / 2016 pp. 28-36 DOI 10.5755/j01.erem.72.4.16585 (c) Kaunas University of Technology
The Effect of Various Sapropel Concentrations on Content and Fluorescence of Photosynthetic Pigments of Bean

Received 2016/10
Accepted after revision 2016/12

\begin{tabular}{|l|l}
\hline Received 2016/10 & Accepted after revision 2016/12 \\
\hline
\end{tabular}

http://dx.doi.org/10.5755/j01.erem.72.4.16585

\title{
The Effect of Various Sapropel Concentrations on Content and Fluorescence of Photosynthetic Pigments of Bean
}

\author{
Martynas Klepeckas, Irena Januškaitienè \\ Vytautas Magnus University, Faculty of Nature Sciences, Vileikos st. 8, LT-44404 Kaunas, Lithuania
}

Corresponding author: Irena.Januskaitiene@vdu.lt

I. Januskaitienè, Vytautas Magnus University, Faculty of Nature Sciences, Vileikos st. 8, LT-44404 Kaunas, Lithuania

The impact of sapropel of Lake Tarosiškis on photosynthesis parameters (content of pigments and chlorophyll $a$ fluorescence) of beans (Vicia faba L.) was investigated in this study. Plants were sown in $1 \mathrm{~L}$ volume pots by 5 seeds with light loamy soil and grown in growth chambers. Considering sapropel composition, 2.2, 3.1 and $4 \mathrm{t} /$ ha dry sapropel concentrations were chosen for investigation. Sapropel-affected plants were compared with plants grown in unfertilised soils and soils fertilised with a synthetic fertiliser. On day 14 of the experiment, when the plants reached 2-leaves growth stage (BBCH 12), chlorophyll a fluorescence parameters of the investigated plants were measured. Then the plants were grown for another 4 weeks, and at the stem elongation stage (BBCH 31), chlorophyll $a$ fluorescence parameters were measured repeatedly and the content of chlorophylls and carotenoids was investigated. The photosystem II efficiency of beans insignificantly increased $(p>0.05)$ by increasing sapropel concentration in the soil. Photosynthesis performance index increased $(r=0.91 ; p<0.05)$ with increasing sapropel concentration up to $3.1 \mathrm{t} /$ ha at BBCH growth stage 12. The same tendency was observed for the electron transport rate of beans $(r=0.9$; $p<0.05)$ at this growth stage, but at a later stage $(\mathrm{BBCH} 31)$ it slightly lowered $(r=-0.02 ; p>0.05)$. At BBCH stage 12 , the highest non-photochemical quenching (NPQ) value was measured in control beans, while at BBCH stage 31, the opposite trend was noticed $(r=0.86 ; p<0.05)$. At BBCH growth stage 31, an increase in sapropel concentration made the bean chlorophyll content to decrease; however, this decrease was insignificant $(r=-0.18, p>0.05)$. The changes in the carotenoid content were similar to chlorophyll $a+b$.

Keywords: bean, sapropel, fertiliser, pigments, fluorescence. 


\section{Introduction}

The use of mineral fertilisers is among key factors driving the increased global agricultural production required to feed the rising human population. Synthetic N compounds produce roughly half of today's world food (Erisman et al., 2008, Bindraban et al., 2015). But the use of inorganic fertilisers has recently become more of a problem than benefit, because often it is related to soil acidity, its quality lowering, nutrient misbalance and lowered yield quality (UN, 2011). The actual humification degree in soil depends on the organic materials applied, soil type and climatic conditions (Ciavatta et al., 1989). Environmental and economic concerns have prompted agricultural producers and researchers to look for improved nutrient management strategies (Sokolov et al., 2008). For plant growth, organic matter concentration in soil is one of the most important components. A strong correlation was found between soil organic matter amount and organic matter amount which is returned to soil when plants are decomposing (Trapani et al., 1999, Sokolov et al., 2008).

The main advantages of organic production are reflected in healthier final output and a positive impact on the environment by reducing pollution, rational use of resources, preservation of soil fertility, etc. Organic production highlights a huge importance of organic fertilisers being used because they improve the properties of soil and final products (Blečić et al., 2014). Soil organic matter represents an equilibrium system, which plays a major role in supplying nutrients for plant growth. Transformation of fresh organic matter to stable humic compounds affects the cation and anion exchange capacity. It is known that under the influence of enzymes, secreted by microorganisms, macromolecules of complex organic compounds are exposed by destruction. The degradation products form heterocyclic compounds, which interact with certain kinds of microorganisms and produce low and high molecular organic substances, such as carbohydrates, lignin and peptides (Schnitzer \& Khan, 1978, Bambalov et al., 2000, Nieder et al., 2003). Sapropel contains a lot of organic matter and other element-rich sediment, and it is naturally formed in water ponds and lakes when water flora and fauna fall to the bottom and decompose. This type of fertilisers is a relatively new concept in agricultural production (Blečić et al., 2014).
Cleaning Lithuanian lakes only, about 400 million tons of dry sapropel could be obtained and successfully used as an organic fertiliser in farming (Kavaliauskiene, 2000, Staugaitis et al., 2011, Valstybinio audito ataskaita $\langle\ldots\rangle, 2009)$. Its composition includes large amounts of nitrogen, phosphorus and potassium, as well as such elements as $\mathrm{Co}, \mathrm{Mn}, \mathrm{Cu}, \mathrm{B}, \mathrm{Br}$, Mo, etc., 17 amino acids, vitamins and enzymes (Agafonova et al., 2015). Sapropel composition can be up to $95 \%$ organic matter of its mass. Its usefulness as a fertiliser has been proven many times (levina et al., 2014). While sapropel composition holds lots of macro- and microelements necessary for plant growth, its wide positive effect surpasses synthetic-organic fertilisers. Sapropel mineralisation is slow; therefore, its positive effect on soil stays for several years (Kavaliauskiene, 2000, Bates and Lynch, 2000). It is also known to strongly increase such processes as photosynthesis, which is the main source of plant energy in the whole biosphere (Lawlor, 2002). The main difference of sapropel from soil is that sapropel has assimilable nitrogen (60-80\%) and has 3 times less biochemically stable fractions. Besides, the fractions are renewed, and according to the existing mutual connection between biologic action of humic acids and their acid renewable state more renewed has a more effective simulative impact on the photosynthesis of plants (Sviridova and Kosulnikova, 2007, Fillery, 2007).

Because of current fertiliser usage trends, many environmental problems are being created; thus, it is important to search for alternatives. Sapropel extraction could be a perfect and ecological solution to this problem with wide usage possibilities.

\section{Materials and methods}

Sapropel of Lake Tarosiškis was investigated in this experiment. The composition of sapropel was investigated at the laboratory of wastewater of UAB Vilniaus vandenys. The content of nitrogen in dry sapropel varied from 54.8 to $78.2 \mathrm{~g} \mathrm{~N} / \mathrm{kg}$ sapropel.

The preparation of sapropel was made according to Booth et al. (2007), i.e., it was frozen at $-10^{\circ} \mathrm{C}$ for 1 week to break its primary structure and to ease its mineralisation. 
According to nitrogen fertilisation limits for organic fertilisers (including sapropel), the concentration of nitrogen in soils is $170 \mathrm{~kg} \mathrm{~N} / \mathrm{ha}$ (91/676/EEB); thus, in 1 ha area, 2.2-3.1 tons of dry sapropel can be added. Having taken into consideration all these facts, 2.2, 3.1 and $4 \mathrm{t} /$ ha dry sapropel concentrations in growth substrate were chosen for investigation.

During the experiment, beans (Vicia faba L.) were grown in $1 \mathrm{~L}$ pots with 5 seeds with light loamy soil mixed with the needed concentration of sapropel. The effect of sapropel on the investigated plants was compared with 2 reference groups of plants grown in unfertilised soil and in soil fertilised with an inorganic fertiliser. The norm of inorganic fertilisers NPK 14-14-14 is $400 \mathrm{~kg} / \mathrm{ha}$; therefore, this amount was recalculated to a required growth area in $1 \mathrm{~L}$ pots for fertilisation.

The plants were grown in growth chambers with controlled climate (photoperiod duration 14 hours) and watered regularly. On day 14 of the experiment, when the plants unfolded 2 leaves (BBCH 12) (Growth stage, 2000), chlorophyll fluorescence parameters were measured. The plants were grown for another 4 weeks until stem elongation stage BBCH 31 (Growth stage, 2000), and then the content of pigments and chlorophyll fluorescence parameters were measured once again.

Concentrations of photosynthesis pigments were analysed in an acetone extract using a spectrophotometer according to Wettstein (1957). Chlorophyll a fluorescence parameters were determined by using Hansatech fluorimeter - Handy Pea. The measurements were performed by applying special clips to healthy leaves, darkening them for $15 \mathrm{~min}$. Then, the measuring sensor was applied to the clipper and the measurement was taken (Hansatech Instruments 2006).

Measured parameters: Fv/Fm - maximum photosystem II quantum efficiency rate; PI - photosynthesis performance index; ETR - electron transport rate, calculated using the formula:

\section{$\mathrm{ETR}=\mathrm{Fv} / \mathrm{Fm}^{*} \mathrm{~F}^{*} \mathrm{PPFD}^{*} \alpha$}

where

ETR - electron transport rate in quants per second $(q / s)$; $\mathrm{v} / \mathrm{Fm}$ - maximum photosystem II quantum efficiency rate; $\mathrm{F}$ - coefficient for C3 plants (0.5); PPFD - fluorimeter photon light stream in quants (1800); $\alpha$ - leaf absorption.
All the measurements were carried out in 3 replications. The Pearson correlation coefficient, $r$, and the $p$-values were used for the assessment of the effect of sapropel concentration on the investigated plant parameters. The Student $t$ test was used for comparison of independent variables. All the analyses were performed by STATISTICA and EXEL, and the results were expressed as mean values and their standard error (SE).

\section{Results and discussion}

Lake sapropel can be a great fertiliser for soils, because its composition contains large amounts of nitrogen, phosphorus, manganese, iron, copper or other microelements. Most of these elements are essential for plant growth and photosynthesis (Broadley et al., 2007). When soil enrichens with nitrogen, the nitrogen content in plant leaves also increases (Evans, 1989). Some research studies have shown that nitrogen deficiency leads to a significantly lower leaf weight (Cechin and Fumis, 2004). Nitrogen is especially important for such plants as beans (Vicia faba L.). The same applies to phosphorus, but it is stored in roots and by demand can be transferred to plant parts which need it most. Besides, phosphorus functions cannot be replaced by any other element. And there it is composed into various organic compounds (Bates and Lynch, 2000, Li et al., 2001, Yong-fu et al., 2006). When a plant is low on manganese or any other microelement, its photosynthesis rates decrease. $\mathrm{Mn}$ is involved in photolysis reactions; thus, in case of its shortage, photosynthesis is disrupted and visual symptoms appear on leaves, and plant dry mass and yield decreases. At the same time, soluble sugar concentration lowers in the whole plant (Demirevska et al., 2004). Thus, fertilisation with micro- and macroelement-rich sapropel helps to remove deficiency of elements for plants in one take, and also improves soil quality (Marschner, 2012, Agafonova et al., 2015).

As for individual photosynthesis parameters, $\mathrm{Fv} / \mathrm{Fm}$ is widely used to indicate the maximum quantum efficiency of photosystem II. This parameter is widely considered to be a sensitive indication of plant photosynthetic performance with healthy samples typically achieving a maximum Fv/Fm value of approximately 0.85 . Values lower than this have been observed if a sample 
was exposed to some type of a biotic or abiotic stress factor, which reduced the capacity for photochemical quenching of energy within PSII (Hansatech Instruments, 2006). Janušauskaite and Feizienè (2012) have found that nitrogen deficiency could be noticed by investigating the Fv/Fm ratio. Some authors disagree that although Fv/Fm contains valuable information on the status of photosynthetic apparatus, it can be non-specific and often insensitive to many environmental effects (Lawlor, 2002, Brestic et al., 2012, Živčák et al., 2014). Our findings also show that photosystem II efficiency of $V$. faba increased with increasing sapropel concentration in the soil; however, the increase was insignificant $(r=0.94 ; p>0.05)$ (Figure 1).

The highest value of Fv/Fm - 0.828 - was measured at $\mathrm{BBCH}$ growth stage 12 under the effect of a synthetic fertiliser, and this value was by $6 \%(p<0.05)$ higher than in control beans; however, if compared with $3.1 \mathrm{t} /$ ha sapropel concentration effect, Fv/Fm of plants increased just slightly $(p>0.05)$. During the second measurement, at BBCH growth stage 31, increasing sapropel concentration did not cause Fv/Fm to increase so strongly as during the first measurement $(r=0.78$; $p>0.05$ ). Under $4 \mathrm{t} /$ ha sapropel concentration, Fv/Fm was by $1.3 \%(p>0.05)$ higher than $\mathrm{Fv} / \mathrm{Fm}$ of beans fertilised with a synthetic fertiliser and only by $0.5 \%$ $(p>0.05)$ higher than that of control plants.

Photosynthesis performance index (PI) is good photosynthetic tissue vitality indicator (Hansatech Instru- ments, 2006). Živčák et al. (2014) has found that in wheat $\mathrm{PI}$ correlates really well with nitrogen amount in plant leaves (young or even older ones), but also they add that the Fv/Fm ratio was almost insensitive to nitrogen amount changes. $\mathrm{Pl}$ is related to photosynthesis reaction centres. When a plant is getting low on nitrogen, the number of reaction centres decreases and $\mathrm{PI}$ reacts to that fairly sensitively. Similar results have been found investigating soy and maize plants (Heerden et al., 2004).

Photosynthesis performance index of beans at $\mathrm{BBCH}$ growth stage 12 increased strongly $(r=0.91 ; p<0.05)$ up to a $3.1 \mathrm{t} /$ ha sapropel concentration increase, when the highest PI was detected, and it was by $28.7 \%(p<0.05)$ higher than that of control plants and by $1 \%(p>0.05)$ higher than PI of $4 \mathrm{t} /$ ha and a synthetic fertiliser-affected beans (Figure 2). However, during the second measurement at a later growth stage (BBCH 31), an opposite tendency was observed, when the PI value lowered significantly $(r=-0.67 ; p<0.05)$ by increasing sapropel concentration in the soil.

The concentrations of macroelements are mostly responsible for a sufficient electron transport rate (ETR) (Lawlor, 1994, Kim et al., 2002, Marschner, 2012). Electron transport can be closely related to nitrogen amount in plants. It is also worth noticing that not only nitrogen determines electron transport, but many other elements and nutrients as well (Lambrev et al., 2012). In this case, most of them can be found in sapropel. The majority of nitrogen is accumulated in leaves, and



Fig. 1

The changes of bean photosystem II efficiency (Fv/Fm) at different sapropel concentrations (t/ha) at $\mathrm{BBCH}$ development stages 12 and 31 (SE*1.96) 
Fig. 2

The changes of bean photosynthesis index (PI) at different sapropel concentrations (t/ha) at BBCH development stages 12 and 31 (SE*1.96)

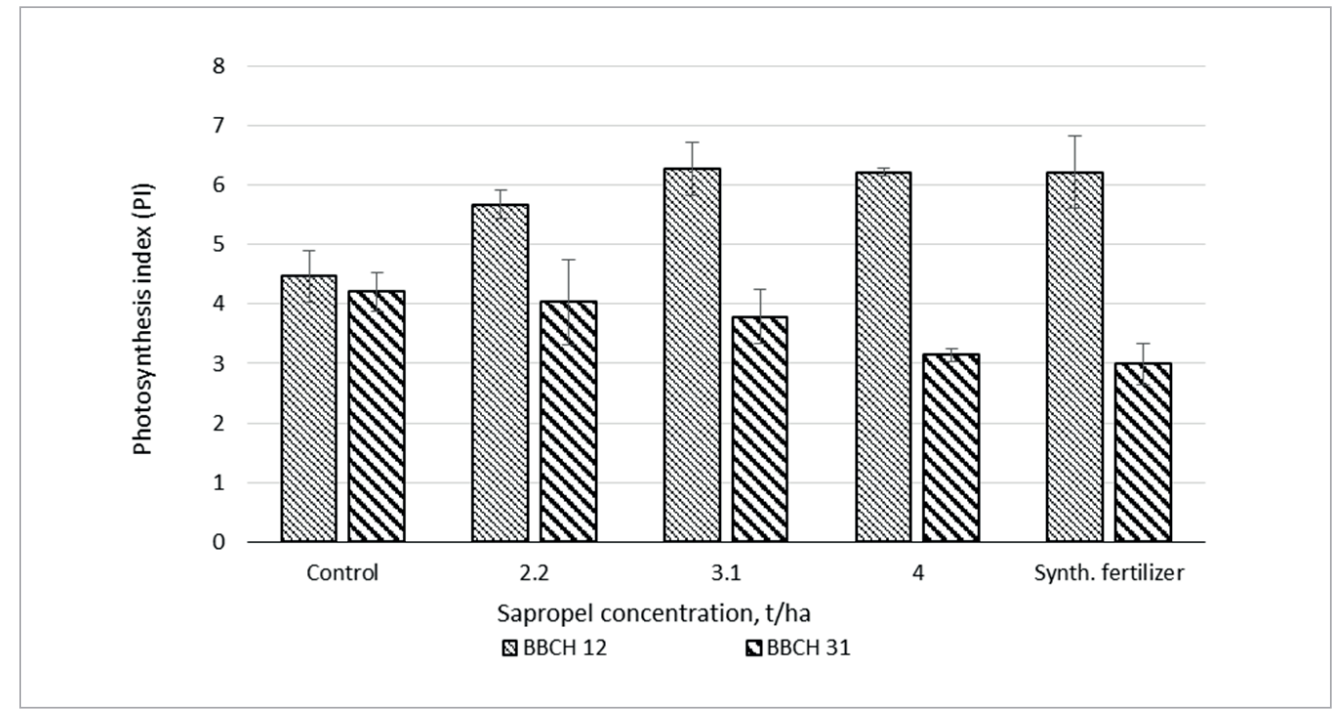

Fig. 3

The changes of a bean electron transport rate (ETR) at different sapropel concentrations (t/ha) at BBCH development stages 12 and 31 (SE*1.96)

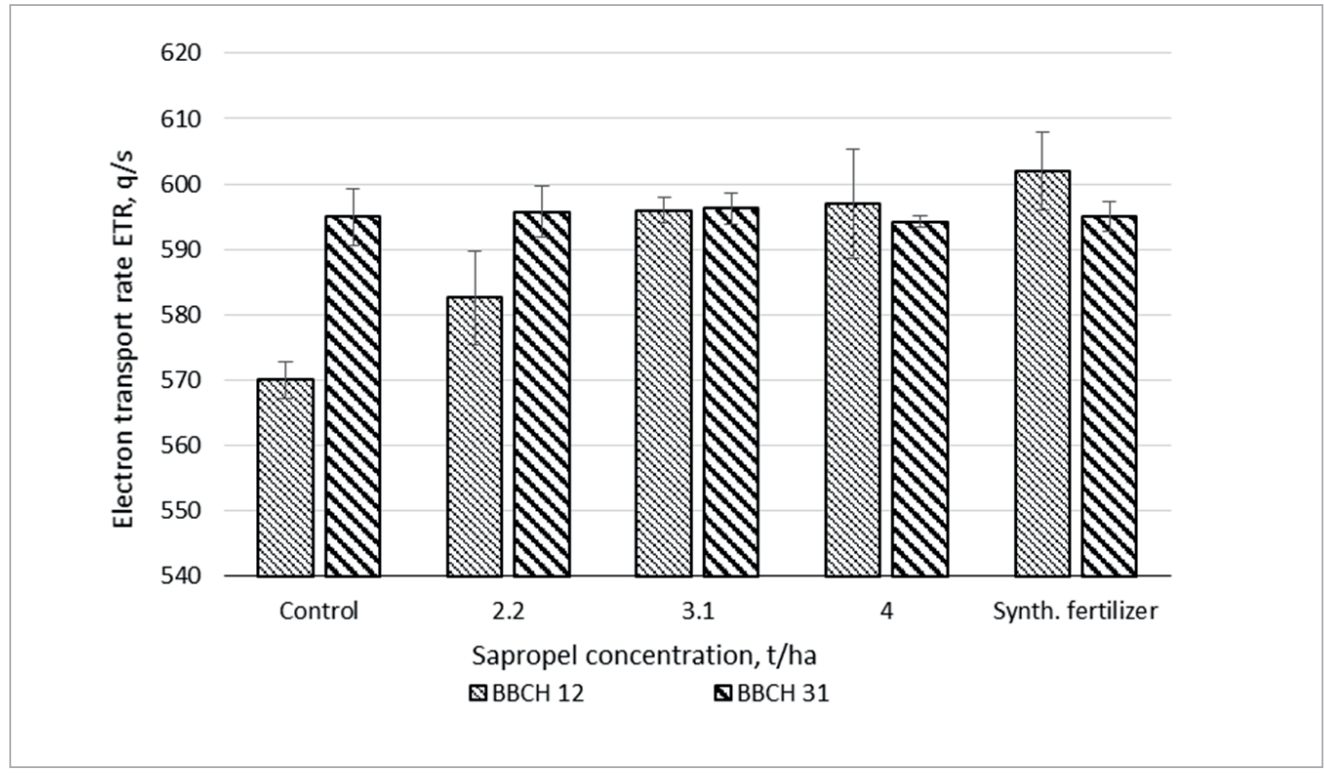

that activates photosynthesis. Because of that, plant leaves show a higher electron transport rate and produce RuBisCO more efficiently during the Calvin cycle (Marschner, 2012). Since nitrogen deficiency lowers photosynthesis efficiency ( $\mathrm{Fv} / \mathrm{Fm})$, it also lowers electron transport rates in rice (Li et al., 2012). In this experiment, it was determined that at $\mathrm{BBCH}$ development stage 12 the electron transport rate of beans increased $(r=0.9 ; p<0.05)$ significantly together with increasing sapropel concentration, although the highest rate was measured in beans fertilised with a synthetic fertiliser.
This ETR was only by $1 \%(p>0.05)$ higher than that of beans affected with 3.1 and $4 \mathrm{t} / \mathrm{ha}$ sapropel in the soil. At a later development stage (BBCH 31), increasing concentration of sapropel led to a light decrease in ETR of beans $(r=-0.02 ; p>0.05)$; however, this decrease was insignificant (Figure 3).

Non-photochemical quenching (NPQ) is a mechanism which indicates how strongly a plant is forced to fight a light-induced damage to its tissues. When a higher value is achieved, higher damage is induced and a plant is forced to use its resources to protect itself. NPQ 
can even be caused by $\mathrm{pH}$ changes in photosystem II (Figueroa et al., 2003). Lambrev et al. (2012) have noticed that nitrogen in plant environment significantly increases photochemical activity (Fv/Fm) and lowers non-photochemical quenching (NPQ) in all development stages of a plant. With additional nitrogen in the environment, NPQ lowers even at drought conditions. In this experiment, when the investigated beans reached $\mathrm{BBCH}$ growth stage 12, it was detected that NPQ lowered significantly $(r=-0.92 ; p<0.05)$ (Figure 4). The highest NPQ value was measured in control beans, and their NPQ was by $63 \%(p<0.05)$ higher than NPQ of $4 \mathrm{t} /$ ha concentration-affected plants and by 66\% $(p<0.05)$ higher than NPQ of beans affected by a synthetic fertiliser. The lowest NPQ was measured in beans with a synthetic fertiliser, and it was by 6.5\% ( $p>0.05)$ lower than $N P Q$ of beans affected by $4 \mathrm{t} /$ ha sapropel. When plants reached $\mathrm{BBCH}$ growth stage 31 , an opposite trend was noticed $(r=0.86 ; p<0.05)$.

An increase in sapropel concentration caused a statistically insignificant decrease in the chlorophyll $a+b$ content in bean leaves $(r=-0.18 ; p>0.05)$ (Figure 5$)$. The

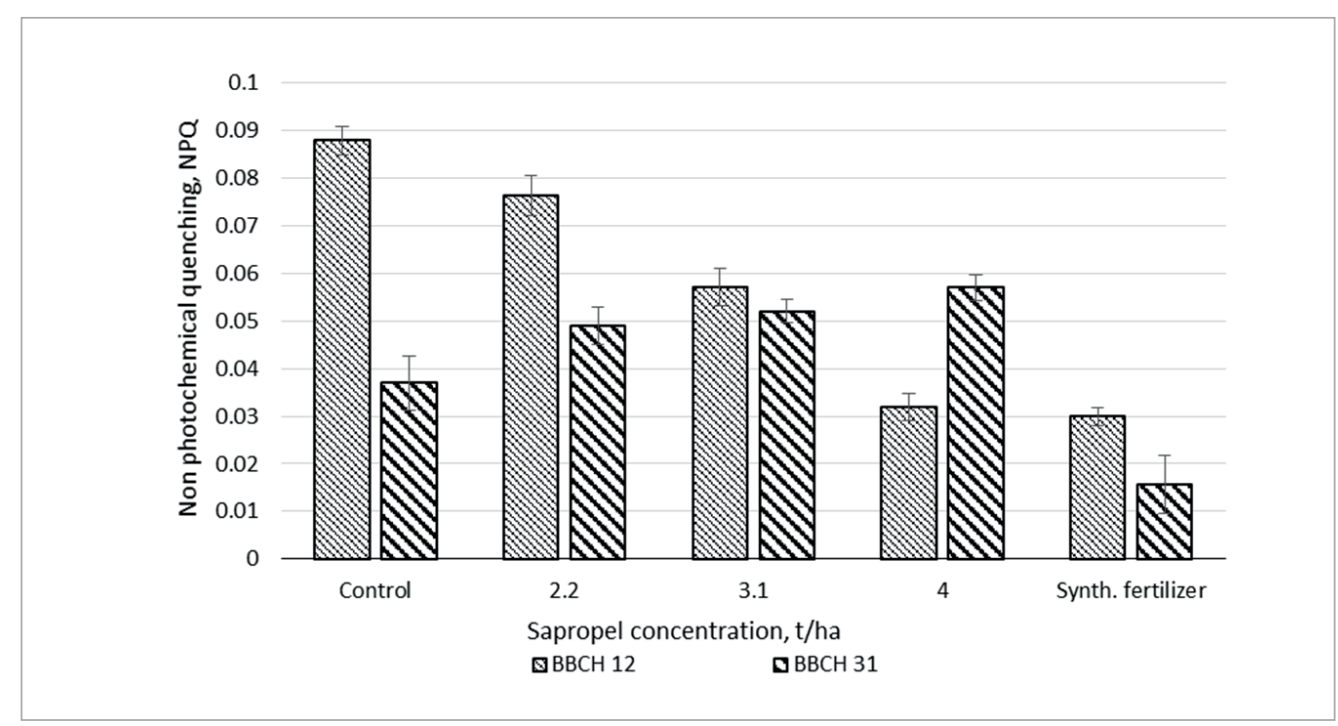

\section{Fig. 4}

The changes of bean non-photochemical quenching (NPQ) at different sapropel concentrations (t/ha) at $\mathrm{BBCH}$ development stages 12 and $31\left(\mathrm{SE}^{\star} 1.96\right)$

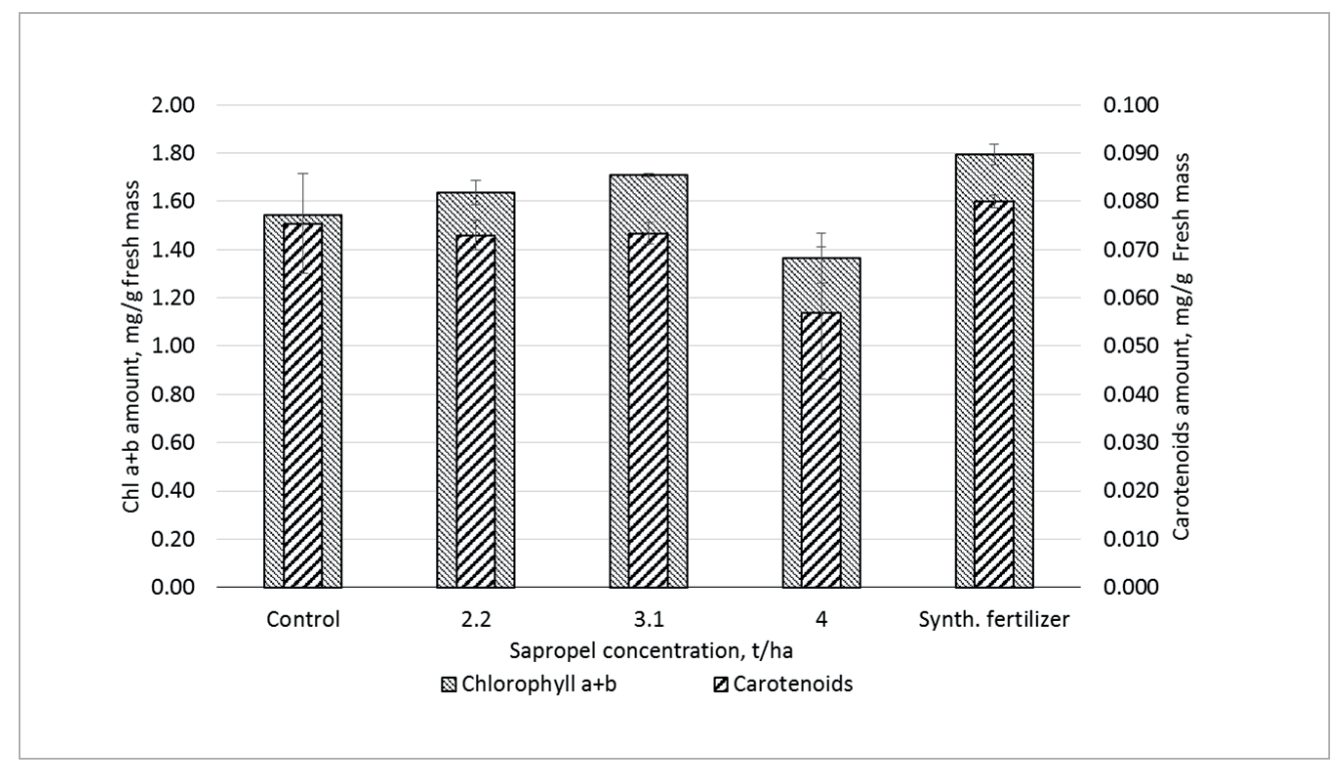

\section{Fig. 5}

The changes of bean chlorophylls $a+b$ and carotenoid content at different sapropel concentrations (t/ha) at $\mathrm{BBCH}$ development stage 31 (SE*1.96) 
highest content of pigments was measured in plants fertilised with a synthetic fertiliser. The changes in the carotenoid content were similar to chlorophyll $a+b$. Chlorophyll is especially sensitive to changes in nutrition elements in soil (Kopsell et al., 2004). For example, nitrogen is an essential element for amino acid, protein or enzyme composition, and a lower amount of $\mathrm{N}$ can lead to slower biochemical reactions of plants, including ones in photosynthesis. Nitrogen is also directly responsible for chlorophyll production (Toth et al., 2002, Kim et al., 2002). Thus, decreased concentration of nutrition elements in sapropel-fertilised soils led to a decrease in content photosynthetic pigments and also lowered the fluorescence parameters of beans at the end of this experiment at $\mathrm{BBCH}$ stage 31 , because the actual content of nutrients helps to slow photosynthesis pigment degradation and prolongs their active photosynthesis period (Juchnevičienè et al., 2015).

\section{Conclusions}

By increasing sapropel concentration in the soil, the efficiency of photosystem II (Fv/Fm) of beans at both investigated growth stages increased, although this in-

\section{References}

Agafonova L., Alsina I., Sokolov G., Kovrik S., Bambalov N., Apse J., Rak M. (2015) New Kinds of Sapropel and Peat Based Fertilizers Environment. Technology. Resources, Vol. II, p. 20-26

Bates T.R., Lynch J.P. (2000) Plant growth and phosphorus accumulation of wild type and two root hair mutants of Arabidopsis thaliana Brassicaceae). Am J Bot, 87, p. 958-963. https://doi.org/10.2307/2656994

Bindraban P. S., Dimkpa Ch., Nagarajan L., Roy A., Rabbinge R. (2015) Revisiting fertilisers and fertilisation strategies for improved nutrient uptake by plants. Biology and Fertility of Soils, Vol. 51, Iss. 8, p. 897-911. https://doi.org/10.1007/s00374-015-1039-7

Blečic A., Railić B., Dubljević R., Mitrović D., Spalevic V. (2014) Application Of Sapropel In Agricultural Production. Agriculture and Forestry, p. 243-250.

Brestic M., Zivcak M., Kalaji M. H., Carpentier R., Allakhverdiev I. S. (2012) Photosystem II thermostability in situ: Environ- crease was insignificant ( $p>0.05)$.

The photosynthesis performance index of beans at BBCH growth stage 12 increased strongly $(r=0.91$; $\mathrm{p}<0.05$ ) by increasing sapropel concentration up to $3.1 \mathrm{t} / \mathrm{ha}$, but at a later stage $(\mathrm{BBCH} 31)$, the changes in the PI value were opposite $(r=-0.67 ; p<0.05)$.

The electron transport rate increased $(r=0.9 ; p<0.05)$ significantly together with increasing sapropel concentration, while the highest ETR was measured in beans fertilised with a synthetic fertiliser.

By increasing sapropel concentration in the soil, NPQ lowered significantly $(r=-0.92 ; p<0.05)$ at BBCH growth stage 12 and the highest NPQ value was measured in control beans. Meanwhile, at BBCH stage 31, the opposite trend was noticed ( $r=0.86 ; p<0.05)$.

An increase in sapropel concentration led to a statistically insignificant decrease in chlorophyll $a+b$ and carotenoid content in bean leaves $(r=-0.18$; $p>0.05$; and $r=-0.5 ; p>0.05$, respectively) at later $\mathrm{BBCH}$ stage 31 .

At early $\mathrm{BBCH}$ growth stage 12, chlorophyll fluorescence parameters of beans increased by increasing sapropel concentration in the soil, but at the end of the experiment at $\mathrm{BBCH}$ stage 31 , when the concentration of nutrients in the soil decreased, all the investigated parameters also decreased.

mentally induced acclimation and genotype-specific reactions in Triticum aestivum L. Plant Physiology and Biochemistry 57. 93-105. https://doi.org/10.1016/j.plaphy.2012.05.012

Broadley M. R., White P. J., Hammond J. P., Zelko I., Lux A. (2007) Zinc in plants. New Phytologist, 173(4), p. 677-702. https://doi.org/10.1111/j.1469-8137.2007.01996.x

Cechin I., Fumis T.F. (2004) Effect of nitrogen supply on growth and photosynthesis of sunflower plants grown in the greenhouse. Plant Science 166. p. 1379-1385. https://doi. org/10.1016/j.plantsci.2004.01.020

Ciavatta C., Antisari L.V., Sequi P. 1989. Humification parameters of organic materials applied to soil. In Bhattacharji, S., Friedman, M., Neugebauer, H.J. \& Seelacher, A. (eds): Humic Substances in the Aquatic and Terrestrial Environment. Springer-Verlag, Berlin, pp.177-185.

Ciftci-Yilmaz S., Mittler R. (2008) The zinc finger network of plants. Cellular and Molecular Life Sciences, 65(7-8), p. 1150- 
1160. https://doi.org/10.1007/s00018-007-7473-4

Demirevska K.K., Simova S.L., Stoyanova Z., Hölzer R., Feller U. (2004) Biochemical changes in barley plants after excessive supply of copper and manganese Environmental and Experimental Botany 52. p. 253-266. https://doi.org/10.1016/j.envexpbot.2004.02.004

Erisman JW, Sutton MA, Galloway JN, Klimont Z, Winiwarter W (2008) How a century of ammonia synthesis changed the world. Nat Geosci 1:636-639. https://doi.org/10.1038/ngeo325

Evans J.R. (1989) Photosynthesis and nitrogen relationship in leaves of C3 plants, Oecologia 78 p. 9-19. https://doi. org/10.1007/BF00377192

Figueroa F.L., Alvarez R.C., Gomez I. (2003) Relations between electron transport rates determined by pulse amplitude modulated chlorophyll fluorescence and oxygen evolution in macroalgae under different light conditions. Photosynthesis Research 75, p. 259-275. ttps://doi. org/10.1023/A:1023936313544

Fillery I.R.P. (2007) Plant-based manipulation of nitrification in soil: A new approach to managing N loss? Plant and Soil 294, p. 1-4. https://doi.org/10.1007/s11104-007-9263-z

Hansatech Instruments. (2006) Handy Handy PEA, Pocket PEA \& PEA Plus Software Operations Manual. Version 1.0 England

Hansch R., Mendel R.R. (2009) Physiological functions of mineral micronutrients (Cu, Zn, Mn, Fe, Ni, Mo, B, Cl) Current Opinion in Plant Biology, 12, p. 259-266. https://doi.org/10.1016/j. pbi.2009.05.006

Heerden P. D., Strasser R. J., Krüger G. H. (2004) Reduction of dark chilling stress in N2-fixing soybean by nitrate as indicated by chlorophyll a fluorescence kinetics. Physiologia Plantarum, 121, p. 239-249. https://doi.org/10.1111/j.00319317.2004.0312.x

levina G. L., Karlsons A., Ozola U. A. (2014) Effect of freshwater sapropel on plants in respect to its growth - affectingactivity and cultivable microorganism content. Zemdirbyste-Agriculture, vol. 101 No. 4, p. 355-366. https://doi.org/10.13080/ z-a.2014.101.045

Janušauskaitè D., Feizienė D. (2012) Chlorophyll fluorescence characteristics throughout spring triticale development stages as affected by fertilization. Soil and Plant Science, 62 (1), p. 7-15. https://doi.org/10.1080/09064710.2011.560122

Juchnevičienè A., Vagusevičienè I., Kaminskaitè A., Brazaitytè A., Duchovskis P. (2015) Azoto trąšų poveikis skirtingu žieminiu kviečiu veisliu fotosintetiniams rodikliams. Žemès Ūkio Mokslai. T. 22. Nr. 1. P. 15-25. https://doi.org/10.6001/zemesukiomokslai.v22i1.3062
Kavaliauskienè J. (2000) Species composition of phytoplankton in some Lithuanian karst lake. The Geographical Yearbook, XXXIV tomas, p. 233-239.

Kim T.H., Mills A., Wetzstein H.Y. (2002) Studies on effects of nitrogen form on growth, development, and nutrient uptake in pecan. Journal of Plant Nutrition 25, p. 497-508. ttps://doi. org/10.1081/PLN-120003378

Kopsell D. A., Kopsell D. E., Lefsrud M. G., Curran-Celentano J., Dukach L. E. (2004) Variation in lutein, $\beta$-carotene and chlorophyll concentrations among Brassica oleracea cultigens and seasons. Hortscience. Vol. 39. No. 2. P. 361-364.

Lambrev P.H., Miloslavina Y., Jahns P., Holzwarth A.R. (2012) On the relationship between non-photochemical quenching and photoprotection of Photosystem II. Biochimica et Biophysica Acta 1817, p.760-769. https://doi.org/10.1016/j.bbabio.2012.02.002

Lawlor D.W. (2002) Carbon and nitrogen assimilation in relation to yield: mechanisms are the key to understanding production systems, J. Exp. Botany 53, p. 773-787. https://doi. org/10.1093/jexbot/53.370.773

Lawlor D.W. 1994. Relation between carbon and nitrogen assimilation, tissue composition and whole plant function. In: A Whole-Plant Perspective on Carbon-Nitrogen Interactions, $p$. 47-60.

Li G., Zhang Z. S., Gao H. Y., Liu P., Dong S. T., Zhang J. W., Zhao B. (2012) Effects of nitrogen on photosynthetic characteristics of leaves from two different stay-green corn (Zea mays L.) varieties at the grain-filling stage. Canadian Journal of Plant Sciences, 92, p. 671-680. https://doi.org/10.4141/cjps2012-039

Li H.B., Xia M., Wu P. (2001) Effect of phosphorus deficiency stress on rice lateral root growth and nutrient absorption. Acta BotSin, 43, p. 1154-1160.

Marschner P. (2012) Marschner's Mineral Nutrition of Higher Plants, 3rd ed.; Academic Press: London, UK, p. 178-189.

Sokolov G., Szajdak L., Simakina I. (2008) Changes in the structure of nitrogen-containing compounds of peat-, sapropel-, and brown coal-based organic fertilizers. Agronomy Research 6 (1), p. 149-160.

Staugaitis G., Mažeika R., Antanaitis A., Antanaitis Š. (2011) Komposto, Naudojamo Žemės Ūkyje, Kokybės Reikalavimu Analizè Ir lvertinimas, Kaunas: Lietuvos Agrarinių Ir Mišku Mokslo Centro Agrocheminių Tyrimų Laboratorija.

Sviridova, L. L., Kosulnikova, T. L. (2007) Elements of photosynthetic productivity of potato depending on fertilizer and moisture. Вестник Белорусской государственной сельскохозяйственной академии (Belarus). Bulletin of the 
Belarus State Agricultural Academy.33. Toth V.R., Meszkaros I., Veres S., Nagy J. (2002) Effects of the available nitrogen on the photosynthetic activity and xanthophyll cycle pool of maize in field, J. Plant Physiol. 159, p. 627-634. https://doi. org/10.1078/0176-1617-0640

Tranavičienè T. (2009) Azoto poveikis skirtingų paprastojo kviečio (Triticum aestivum L.) veislių fotosintezès ir grūdų kokybės rodikliams: daktaro disertacija. Akademija, Kauno r. 89 p.

Trapani N., Hall A.J., Weber M. (1999) Effects of constant and variable nitrogen supply on sunflower (Helianthus annuus L.) leaf cell number and size, Ann. Botany 84, 599-606. https:// doi.org/10.1006/anbo.1999.0954

UNITED NATIONS FOOD AND AGRICULTURE ORGANIZATION. (2011) Current world fertilizer trends and outlook to 2015. Rome. p. 43
VALSTYBINIO AUDITO ATASKAITA ŽEMĖS GELMIŲ NAUDOJIMAS 2009 m. gegužès 28 d. Nr. VA-P2-20-3-11 Vilnius, 1-56.

Wettestein D. (1957) Chlorophyll Letale und der submikroskopishe Formveschel der Plastiden. Experimental cell research, 12, p. https://doi.org/10.1016/0014-4827(57)90165-9

Yong-fu L., An-cheng L., Hassan M.J., Xing-hua W. (2006) Effect of Phosphorus Deficiency on Leaf Photosynthesis and Carbohydrates Partitioning in Two Rice Genotypes with Contrasting Low Phosphorus Susceptibility, Rice Science, 13(4), p. 283-290.

Živčák M., Olšovsk K., Slamka P., Galambošová J., Rataj V., Shao H.-B., Kalaji H. M., Brestič M. (2014) Azoto trūkumo nustatymas kviečiuose matuojant skirtingose pozicijose esančių lapu fluorescenciją. Zemdirbyste-Agriculture, vol. 101, No. 4, p. 437-444. https://doi.org/10.13080/z-a.2014.101.056
Skirtingų sapropelio koncentracijų poveikis pupelių fotosintezès pigmentų kiekiui ir fluorescencijai

\section{Martynas Klepeckas, Irena Januškaitienė \\ Vytauto Didžiojo Universitetas, Gamtos mokslų fakultetas, Kaunas, Lietuva}

Šio darbo tikslas - ištirti Tarosiškio ežero sapropelio poveiki pupeliu (Vicia faba L.) fotosintezès rodikliams (pigmentų kiekiui ir chlorofilo a fluorescencijai). Augalai buvo sejjami i 1 I talpos indus su lengvo priemolio dirvoja po 5 sèklas ir auginami fitokamerose. Atsižvelgiant i sapropelio sudeti, tyrimams pasirinktos 2,2; 3,1 ir 4 t/ha sauso sapropelio koncentracijos. Sapropelio poveikis lygintas su augalais, augintais be trąšu ir tręštais sintetinèmis trąšomis. Keturioliktą eksperimento dieną, kai augalai išleido du lapus (BBCH 12), buvo išmatuoti chlorofilo a fluorescencijos rodikliai. Augalus paauginus dar 4 savaites iki stiebu ilgejjimo etapo (BBCH 31), pakartotinai buvo išmatuoti chlorofilo a fluorescencijos rodikliai ir nustatyti chlorofilu bei karotinoidų kiekiai lapuose. Pupelių II fotosistemos darbo efektyvumas didejant sapropelio koncentracijai dirvožemyje išaugo, bet nežymiai ( $p>0,05)$. BBCH 12 augimo etape pupelių fotosintezès indeksas didejo sapropelio koncentracijai didejant iki 3,1 t/ha $(r=0,91 ; p<0,05)$. Šiame augimo etape ta pati tendencija buvo nustatyta ir pupeliu elektrony transporto intensyvumui $(r=0,9 ; p<0,05)$, tačiau veliau (esant BBCH 31 etapui), jtaka sumažejo ( $r=-0,02 ; p>0,05)$. Aukščiausias nefotocheminis malšinimas (NPQ) buvo nustatytas kontroliniu pupeliu esant $\mathrm{BBCH} 12$ etapui, tuo tarpu vèliau (BBCH 31 etape) gauta priešinga tendencija $(r=0,86 ; p<0,05)$. BBCH 31 augimo etape sapropelio koncentracijos didejjimas lèmé pupeliu chlorofilu kiekio mažejimą, tačiau statistiškai nereikšmingai ( $r=-0,18, p>0,05)$, karotinoidų kiekio pokyčiai buvo panašūs kaip ir chlorofilų $a+b$.

Raktiniai žodžiai: pupelès, sapropelis, trąšos, pigmentai, fluorescencija. 